\title{
Michał Kania, Umowa o partnerstwie publiczno-prywatnym. \\ Studium administracyjno-prawne, Wydawnictwo Uniwersytetu Śląskiego, Katowice 2013, ss. 398
}

DOI: http://dx.doi.org/10.12775/SIT.2014.022

Partnerstwo publiczno-prywatne (dalej: PPP) stanowi rodzaj współpracy między podmiotami sektora publicznego a partnerami z sektora prywatnego, w ramach której podmioty te dążą wspólnie do realizacji określonego przedsięwzięcia, dzieląc między sobą zadania oraz ryzyko. Mimo dużej popularności realizacji inwestycji $\mathrm{w}$ formule PPP na całym świecie oraz wielowiekowej historii ${ }^{1}$ tego rodzaju współpracy, w Polsce ten obszar dopiero zaczyna się rozwijać. Pod rządami Ustawy z dnia 28 lipca 2005 r. o partnerstwie publiczno-prywatnym ${ }^{2}$ nie zrealizowano żadnej inwestycji, dopiero obecna Ustawa $z$ dnia 19 grudnia 2008 r. o partnerstwie publiczno-prywatnym ${ }^{3}$, wprowadzająca wiele znaczących zmian (w szczególności ułatwień) w stosunku do jej poprzedniczki, znajduje swoje

${ }^{1}$ Historia partnerstwa publiczno-prywatnego (PPP) sięga czasów Cesarstwa Rzymskiego, aczkolwiek we współczesnej formie pojawiło się ono w Europie dopiero w latach 90. XX wieku. Szerzej P. Nowicki, Partnerstwo publiczno-prywatne, w: System zamówień publicznych w Polsce, red. J. Sadowy, s. 424-425.

${ }^{2}$ Dz.U. Nr 169, poz. 1420.

${ }^{3}$ Dz.U. z 2009 r., Nr 19, poz. 100 ze zm. 
odzwierciedlenie w praktyce. Taki stan rzeczy nie jest jednak jedynie konsekwencją nowych regulacji dotyczących PPP, lecz przede wszystkim wynika $z$ konieczności poszukiwania alternatywnych źródeł finansowania inwestycji przez sektor publiczny, który musi z jednej strony mierzyć się ze skutkami kryzysu gospodarczego, a $z$ drugiej zaś dostarczać społeczeństwu infrastrukturę i usługi o coraz większej jakości. W szczególności widać to na przykładzie jednostek samorządu terytorialnego, których możliwości finansowe zmniejszają się z realizacją każdego kolejnego projektu współfinansowanego ze środków Unii Europejskiej. Partnerstwo publiczno-prywatne staje się zatem interesującą alternatywą dla „tradycyjnych” zamówień publicznych, pozwalając sektorowi publicznemu na dalsze inwestycje w oparciu o kapitał oraz doświadczenie i know-how partnerów $Z$ sektora prywatnego. $Z$ kolei sektor prywatny uzyskuje w drodze PPP możliwość realizacji wieloletnich umów gwarantujących stabilność wynagrodzenia, co pozwala na względną stabilizację, szczególnie istotną w niepewnych czasach kryzysu. Michał Kania słusznie jednak wskazuje, że najważniejszy wpływ na podjęcie decyzji o wykorzystywaniu PPP powinny mieć korzyści wynikające z podnoszenia jakości infrastruktury i świadczonych usług ${ }^{4}$.

Wraz $\mathrm{z}$ rozwojem PPP $\mathrm{w}$ praktyce polska doktryna prawnicza rozpoczęła tworzenie naukowych fundamentów dla prawidłowego funkcjonowania tej instytucji. Należy zauważyć, że na polskie piśmiennictwo prawnicze jest dość ubogie, jeśli chodzi o naukowe opracowania i analizy dotyczące PPP, aczkolwiek ostatnimi czasy można zaobserwować dość intensywny progres w tej sferze. Partnerstwo publiczno-prywatne jest głównie analizowane $z$ perspektywy polskiego publicznego prawa gospodarczego oraz prawa gospodarczego Unii Europejskiej. Z dużą satysfakcją należy również podkreślić wzrastające zaangażowanie przedstawicieli nauk ekonomicznych w powstający dorobek naukowy w dziedzinie PPP.

${ }^{4}$ Jak jednak wskazuje raport Najwyższej Izby Kontroli "Realizacja przedsięwzięć w systemie partnerstwa publiczno-prywatnego" z kwietnia 2013 roku, podmioty publiczne najczęściej decydują się na realizację przedsięwzięć w formule partnerstwa publiczno-prywatnego, biorąc pod uwagę jedynie względy finansowe, związane $z$ ich ograniczonymi możliwościami finansowymi. 
Na tym polu recenzowana monografia dr. hab. Michała Kani (pracę opublikował jeszcze jako doktor nauk prawnych) jawi się jako pozycja godna najwyższej uwagi, której znaczenia nie można nie doceniać. Michał Kania, adiunkt w Katedrze Publicznego Prawa Gospodarczego na Wydziale Prawa i Administracji Uniwersytetu Śląskiego, radca prawny, od wielu lat publikuje, jako autor bądź współautor, prace dotyczące PPP. W jego dorobku naukowym można spotkać wiele przyczynków, niezwykle pozytywnie ocenianych zarówno $\mathrm{z}$ perspektywy teorii, jak i praktyki PPP. Jednak w mojej ocenie monografia Umowa o partnerstwie publiczno-prywatnym. Studium administracyjnoprawne stanowi najbardziej istotny wkład autora w rozwój podwalin naukowych PPP w Polsce. Autor przedstawił bowiem czytelnikom de facto pierwsze w Polsce dogłębne przeanalizowanie problemu charakteru prawnego umowy o PPP. Co więcej, autor nie stronił od stawiania wniosków de lege ferenda, konfrontując istniejące rozwiązania ze stanem postulowanym. Istotny jest również fakt, że dr hab. Michał Kania wskazuje pewne gotowe rozwiązania, które mutatis mutandis mogłyby zostać wprowadzone w polskim porządku prawnym, wynikające $z$ doświadczeń państw, w których PPP jest bardziej rozwinięte i szerzej stosowane niż w Polsce. Przede wszystkim zaś autor w toku całej pracy podkreśla jeden, jakże istotny, fakt: zrozumienie istoty umowy o PPP, jej możliwości i ograniczeń, pozwoli na jej prawidłowe skonstruowanie, co odbije się pozytywnie na całej realizacji przedsięwzięcia $\mathrm{w}$ formule PPP.

Sformułowane przez autora założenia badawcze mają swoje odbicie w układzie recenzowanej publikacji. Została ona podzielona na siedem rozdziałów. W rozdziale I, zatytułowanym „Partnerstwo publiczno-prywatne jako metoda realizacji zadań publicznych”, Michał Kania opisuje przede wszystkim genezę PPP. Autor słusznie analizuje rozwój PPP nie tylko w jego formule per se, lecz również koncesji na roboty budowlane oraz usługi ${ }^{5}$. Uwzględnia w swoich

${ }^{5}$ Warto przy tym wspomnieć, że autor w swojej publikacji powtarza pojawiający się od kilkunastu lat w polskiej literaturze pogląd, zgodnie z którym pierwsze koncesje pojawiły się we Francji dopiero w XV wieku. Jednak ostatnie badania historyków prawa francuskiego wskazują, że koncesje pojawiły się we 
rozważaniach procesy prywatyzacyjne, wskazując, że PPP stanowi rodzaj prywatyzacji funkcjonalnej. Odnosi się także do rozwiązań przyjmowanych na szczeblu Unii Europejskiej.

W rozdziale II pt. „Teoretyczno-prawne podstawy partnerstwa publiczno-prywatnego" Michał Kania koncentruje się na analizie wpływu struktury norm zadaniowych na postulowany sposób regulacji konstrukcji umowy o PPP. Punktem wyjścia dla autora stały się dwa pytania: po pierwsze, jaka jest struktura norm prawnych związanych z PPP, a po drugie, czy ze struktury tych norm wynikają jakieś konsekwencje wpływające na treść umowy o PPP. Co ciekawe, analizując zarysowany obszar, autor początkowo odnosi się do koncepcji Ronalda Dworkina oraz Roberta Alexy'ego, dzielących normy prawne na reguły (rules) i zasady (principles), by następnie badać normy prawne związane $z$ PPP w oparciu o koncepcję norm programowych oraz badania przedstawione w latach 90. XX wieku przez Manuela Atienzę oraz Juana Ruiza Manera, które stanowią bardziej adekwatne tło badawcze dla wybranego przez autora obszaru. Na końcu rozdziału Michał Kania wprowadza czytelnika w problematykę dotyczącą już samej umowy o PPP, uzależniając skuteczność realizacji przedsięwzięcia w tej formule od jej konstrukcji w taki sposób, aby umowa ta stała się środkiem optymalnej realizacji zadań publicznych.

Punktem wyjścia dla kolejnych trzech rozdziałów, tj. rozdziału III, noszącego tytuł „Umowa w systemie prawnych form działania administracji publicznej”, rozdziału IV, zatytułowanego „Cechy umowy administracyjnej” oraz rozdziału V - „Umowa o partnerstwie publiczno-prywatnym w kontekście cech umowy administracyjnej”, jest tzw. umowa administracyjna. Omawiane rozdziały, a zwłaszcza rozdział V, stanowią zasadniczą część recenzowanej publikacji. Autor słusznie wskazuje, że umowa o PPP posiada cechy umowy administracyjnej, do których zaliczył:

- posiadanie przez jedną ze stron umowy statusu publicznoprawnego,

Francji już w wieku XII. X. Bezançon, Histoiredudroitconcessionnaire en France, „Entreprises et histoire” 2005, no 38, s. 26. 
- związanie treści umowy ze sferą zadań publicznych oraz bezpośrednie wywoływanie przez umowę skutków w sferze prawa administracyjnego,

- ukierunkowanie na realizację interesu publicznego,

- znaczne ograniczenie bądź całkowite wyłączenie zasady swobody umów,

- posiadanie uprzywilejowanej, silnej pozycji przez podmioty publiczne wobec kontrahentów.

Szeroka analiza umowy o PPP pod kątem cech umowy administracyjnej stanowi jeden $z$ najbardziej interesujących, a zarazem twórczych elementów recenzowanej publikacji, ponieważ autor po raz pierwszy w polskiej doktrynie prawniczej dokonuje analizy w takiej właśnie sferze. Ciekawym elementem jest również odniesienie konstrukcji umowy o PPP do rozwiązań przyjętych w ustawach regulujących zasady wybory partnera prywatnego: Ustawie $z$ dnia 29 stycznia 2004 r. Prawo zamówień publicznych oraz Ustawie z dnia 9 stycznia 2009 r. o koncesji na roboty budowlane lub usługi.

Należy szczególnie podkreślić fakt, iż Michał Kania nie zawęża swojej analizy umowy o PPP jedynie do perspektywy administracyjnoprawnej, podkreślając, że konstrukcja tego rodzaju umowy może opierać się na rozwiązaniach charakterystycznych dla reżimu prawa prywatnego, w tym przede wszystkim swobody kontraktowania zawartej w przepisie art. $353^{1}$ k.c. i równorzędnej pozycji stron, a jednocześnie istnieje możliwość skonstruowania tejże umowy w oparciu o rozwiązania typowe dla umowy administracyjnej.

W rozdziale VI - „Umowa o partnerstwie publiczno-prywatnym w typologii umów cywilnoprawnych" - autor charakteryzuje umowę o PPP z punktu widzenia prawa cywilnego, wskazując że jest to umowa dwustronnie zobowiązująca, umowa wzajemna, nazwana, kauzalna, konsensualna, o charakterze odpłatnym. Warto jednak podkreślić, że zdaniem autora umowa o PPP oparta o klasyczne zasady prawa prywatnego nie stanowi środka zapewniającego organom administracji publicznej optymalną realizację zadań publicznych $\mathrm{w}$ formule współpracy $\mathrm{z}$ sektorem prywatnym. Dlatego też niektóre Z cech umowy administracyjnoprawnej mogą odpowiadać potrzebom administracji publicznej, wynikającym ze specyfiki realizacji 
przedsięwzięć w formule PPP. Egzemplifikację stanowi chociażby ukierunkowanie umowy na realizację interesu publicznego czy ograniczenie swobody umów. Autor wskazuje również na konieczność posiadania przez stronę publiczną silnej, uprzywilejowanej pozycji w ramach zawartej umowy o PPP, która umożliwi jej wpływanie na działania partnera prywatnego. W tym miejscu zaznaczyć należy, że PPP opiera się na podziale zadań i ryzyka między podmiotem publicznym i partnerem prywatnym, jednakże nie oznacza to, że stosunek zobowiązaniowy łączący obie strony umowy musi być równorzędny. Istnienie instrumentów nadzorczych po stronie podmiotu publicznego w stosunku do realizacji przedsięwzięcia przez partnera prywatnego nie przenosi bowiem żadnego dodatkowego ryzyka na tego ostatniego, natomiast stanowić może wyraz dbałości o interes publiczny.

Ostatni rozdział zawiera konkluzje i postulaty de lege ferenda w zakresie umowy o PPP. Michał Kania słusznie zauważa, że rozwiązania legislacyjne, które w sposób zamknięty określałyby wszystkie elementy tego typu umowy, byłyby błędne i niewłaściwe ze względu na różnorodność stosunków zobowiązaniowych, w których może znaleźć się podmiot publiczny, realizując przedsięwzięcie we współpracy z sektorem prywatnym. Oprócz koncepcji ujednolicenia niektórych rozwiązań prawnych, np. dotyczących realizacji interesu publicznego, autor podkreśla to, co w mojej ocenie jest najważniejsze - konieczność powrotu do obowiązkowego przeprowadzania analiz mających na celu ustalenie zasadności realizacji PPP. Bez przedmiotowych analiz nie sposób bowiem ustalić i odpowiednio rozłożyć ryzyko pomiędzy strony umowy o PPP, a w konsekwencji prawidłowo podzielić zadania. Wobec braku takich odpowiednich działań przygotowawczych niemożliwe staje się odpowiednie ukształtowanie umowy o PPP.

Reasumując, recenzowana monografia stanowi niezwykle wartościową pozycję. Szczególnie istotne, zarówno z punktu widzenia teorii, jak i praktyki PPP, wydaje się zestawienie cech umowy o PPP przedstawianych $z$ perspektywy umowy administracyjnoprawnej oraz rozwiązań typowych dla umowy cywilnoprawnej. Nie bez znaczenia są także postulaty de lege ferenda, które należy polecić uwadze prawodawcy. 